\title{
Temporal patterns in lacustrine stable isotopes as evidence for climate change during the late glacial in the Southern European Alps
}

\author{
Walter Finsinger $\cdot$ Claudio Belis · Simon P. E. Blockley $\cdot$ Ueli Eicher • \\ Markus Leuenberger · André F. Lotter · Brigitta Ammann
}

Received: 15 August 2007/ Accepted: 4 March 2008/Published online: 26 March 2008

(C) The Author(s) 2008

\begin{abstract}
We investigated oxygen and carbon isotopes of bulk carbonate and of benthic freshwater ostracods (Candona candida) in a sediment core of Lago Piccolo di Avigliana that was previously analyzed for pollen and loss-on-ignition, in order to reconstruct environmental changes during the late glacial and early Holocene. The depth-age relationship of the sediment core was established using 14 AMS ${ }^{14} \mathrm{C}$ dates and the Laacher See Tephra. While stable isotopes of bulk carbonates may have been affected by detrital input and, therefore, only indirectly reflect climatic changes, isotopes measured on ostracod shells
\end{abstract}

W. Finsinger $(\varangle)$ A A. F. Lotter

Palaeoecology, Institute of Environmental Biology, Faculty of Sciences, University of Utrecht, Laboratory of Palaeobotany \& Palynology, Budapestlaan 4, 3584 Utrecht, CD, The Netherlands

e-mail: w.finsinger@uu.nl

C. Belis

Via Pace, 19, 23020 Montagna in Valtellina, SO, Italy

S. P. E. Blockley

Research Laboratory for Archaeology and the History of Art, University of Oxford, South Parks Road,

Oxford OX1 3QY, UK

\section{U. Eicher · M. Leuenberger}

Climate and Environmental Physics, University of Bern, Sidlerstrasse 5, 3012 Bern, Switzerland

\section{B. Ammann}

Institute of Plant Sciences, University of Bern,

Altenbergrain 21, 3013 Bern, Switzerland provide unambiguous evidence for major environmental changes. Oxygen isotope ratios of ostracod shells $\left(\delta^{18} \mathrm{O}_{\mathrm{C}}\right)$ increased by $\sim 6 \%$ at the onset of the Bølling ( $\sim 14,650 \mathrm{cal} \mathrm{BP})$ and were $\sim 2 \%$ lower during the Younger Dryas ( $\sim 12,850$ to 11,650 cal BP), indicating a temporal pattern of climate changes similar to the North Atlantic region. However, in contrast to records in that region, $\delta^{18} \mathrm{O}_{\mathrm{C}}$ gradually decreased during the early Holocene, suggesting that compared to the Younger Dryas more humid conditions occurred and that the lake received gradually increasing input of ${ }^{18} \mathrm{O}$-depleted groundwater or river water.

Keywords Stable isotopes - Ostracods - Climate . Pollen · Late glacial · Laacher See Tephra · Italy

\section{Introduction}

The late glacial is a period of major and rapid environmental changes that was studied intensively. In the North Atlantic region (including Central Europe) the main climatic changes include a rapid warming at the onset of the Bølling ( 14,650 cal BP), a distinct cooling at the onset of the Younger Dryas (YD, $\sim 12,850$ to $\sim 11,650$ cal BP) followed by a rapid warming at the YD/Holocene transition (e.g. Rasmussen et al. 2006). The YD represents a geographically widespread climatic change and models and data agree on the involvement of the meridional overturning 
circulation (MOC, see for discussion Alley 2007). In the Southern European Alps, increasing oxygenisotope ratios $\left(\delta^{18} \mathrm{O}\right)$ from lacustrine carbonates indicate a climate warming at the onset of the Bølling but no signal could be detected from such records for the YD (Eicher 1987; Baroni et al. 2001, 2006). Still, two chironomid-inferred mean July-air temperature records indicate a warming of $\sim 3^{\circ} \mathrm{C}$ at the $\mathrm{B} \varnothing$ lling onset and a $\sim 1.5$ to $\sim 2^{\circ} \mathrm{C}$ cooling during the YD (Heiri et al. 2007; Larocque and Finsinger 2008) and pollen records indicate vegetation responses to these climatic changes (e.g. Finsinger et al. 2006; Vescovi et al. 2007).

The Southern European Alps lie at the northern limit of the Mediterranean Basin, which is located in a climatically sensitive transitional zone between Central Europe (temperate climate) and North Africa (subtropical climate) (Fig. 1). Due to the proximity of this region to the Mediterranean Basin, Eicher (1987) suggested that the missing evidence in $\delta^{18} \mathrm{O}$ records for the YD cooling and the subsequent climate warming at the YD/Holocene transition may be explained by a strong influence of the mediterranean climate. However, $\delta^{18} \mathrm{O}$ records in the eastern and southern Mediterranean indicate a dry climate (marked by higher $\delta^{18} \mathrm{O}$ values) during the YD (Bar-Matthews et al. 1997, 1999; Stevens et al. 2001; Roberts et al. 2001; Wick et al. 2003). Hence Wright et al. (2003) suggested that somewhere between Central Europe and the southern Mediterranean isotopic depletion due to cooling and isotopic enrichment due to evaporation could balance each other if cool and dry YD climatic conditions occurred.

Here we present a new record of stable isotopes measured on bulk carbonates $\left(\delta^{18} \mathrm{O}_{\mathrm{B}}\right)$ and on monospecific ostracod shells $\left(\delta^{18} \mathrm{O}_{\mathrm{C}}\right)$ of Candona candida that were collected from a well-dated sediment record of Lago Piccolo di Avigliana in the Southern European Alps. This record provides strong evidence for major late glacial and early Holocene climate variations that enable teleconnections between the southern Mediterranean and the North Atlantic climate systems.

\section{Regional setting}

Lago Piccolo di Avigliana (LPA; $45^{\circ} 03^{\prime} \mathrm{N}, 07^{\circ} 23^{\prime} \mathrm{E}$; $350 \mathrm{~m}$ a.s.1.) is located in the southern foreland of the Alps (Fig. 1). The catchment $\left(8.1 \mathrm{~km}^{2}\right)$ is surrounded by hills lower than $\sim 650 \mathrm{~m}$ a.s.l. and is characterized by metamorphic rocks (calcareous schists, serpentine, peridotite; Petrucci et al. 1970). The lake (max. depth $12.5 \mathrm{~m}$, surface area 60 ha, water-residence time $\sim 0.9$ years; Gaggino and Cappelletti 1984) is dammed by a moraine system deposited by a lateral

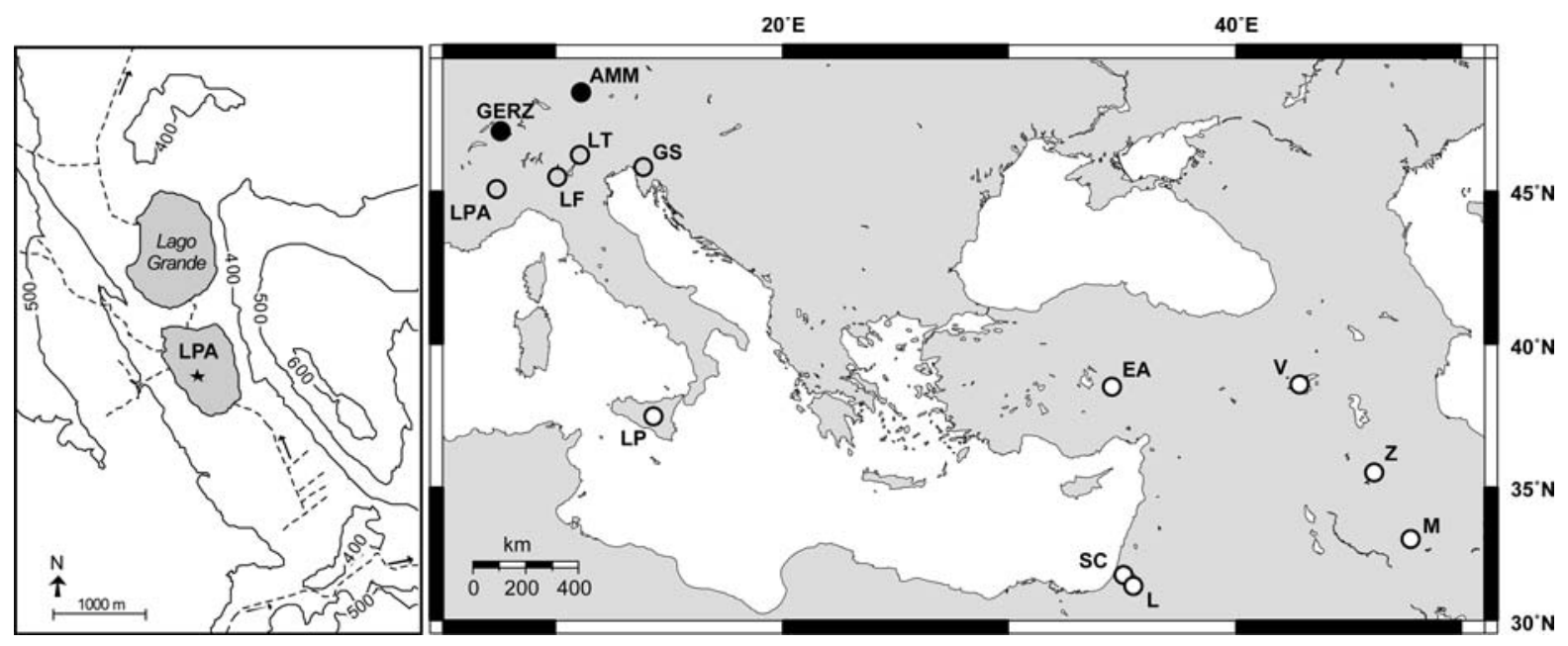

Fig. 1 Left: Map of the Lago Piccolo di Avigliana (LPA) area with coring location marked by the solid star. Right: Location of sites mentioned in the text. Southern Central Europe (filled circles): Ammersee (AMM), Gerzensee (GERZ). Southern European Alps (shaded circles): LPA, Lake Terlago (LT), Lake
Frassino (LF), and Grotta Savi (GS). Mediterranean region: Lake Pergusa (LP), Eski Acıgöl (EA), Lake Van (V), Lake Zeribar (Z), Lake Mirabad (M), Soreq Cave (SC), and Lake Lisan (L) 
tongue of the Susa valley glacier and receives its water from two seasonal streams and from an infilled lake (Torbiera di Trana). Mean annual temperature at Avigliana is $13.0^{\circ} \mathrm{C}$, while mean temperature of the coldest and warmest months are $2.2^{\circ} \mathrm{C}$ (January) and $23.9^{\circ} \mathrm{C}$ (July), respectively (Biancotti et al. 1998). The average sum of annual precipitation amounts to $880 \mathrm{~mm}$, with major rainfall occurring mainly in autumn and spring in connection with the activity of the Genoa Low, a cyclonic circulation over the Gulf of Genoa where cyclones are formed mostly in the lee of the Alps. This in turn is influenced by seasonal latitudinal shifts of the polar front (Pinna 1977). Present-day $\delta^{18} \mathrm{O}$ of precipitation $\left(\delta^{18} \mathrm{O}_{\mathrm{P}}\right)$ on the western Po Plain seems to be influenced by the shadow effect of the Alps (Dray et al. 1997) although this effect is not well defined due to a lack of collecting stations in this sector of the Alps (Longinelli and Selmo 2003). During the YD only small cirque glaciers remained in the Susa valley, none of which was located in the hydrological catchment of the lake (Carraro et al. 2002).

\section{Materials and methods}

Fieldwork and laboratory work

The lake sediments were collected with a modified piston corer (diameter: $8 \mathrm{~cm}$, Merkt and Streif 1970) from a floating platform at a water depth of $12.5 \mathrm{~m}$ in autumn 2001 (Fig. 1b). The one-meter long drives were extruded into plastic half-tubes, wrapped in plastic foil, transported to the laboratory, stored at $4^{\circ} \mathrm{C}$, and subsequently sub-sampled.

Stable oxygen and carbon isotopes were measured on bulk calcium carbonate $\left(\delta_{\mathrm{B}} ; 105\right.$ samples: $861-$ $646 \mathrm{~cm}$ depth), adult Candona candida shells $\left(\delta_{\mathrm{CA}}\right.$; 12 samples: $849-654 \mathrm{~cm}$ depth), and juvenile $C$. candida shells ( $\delta_{\mathrm{CJ}}$; 17 samples: 849-654 cm depth). Sediments for $\delta_{\mathrm{B}}$ were treated and measured as described by Siegenthaler and Eicher (1986). Isotopic composition of ostracod shells $\left(\delta_{\mathrm{C}}\right)$ was measured with a Kiel III ThermoFinnigan device that was coupled to a MAT 250 through a custom-made communication and interface system. Sample weights ranged from 10 to $220 \mu \mathrm{g}$. Values are reported in the standard delta per mille notation relative to the PDB standard $(\% \mathrm{PDB})$. The analytical precision is 0.1 and
$0.15 \%$ for $\delta^{13} \mathrm{C}$ and $\delta^{18} \mathrm{O}$, respectively. Samples for pollen analysis $\left(1 \mathrm{~cm}^{3}\right)$ were prepared by decanting and sieving at $500 \mu \mathrm{m}$ before standard chemical treatment $(\mathrm{HCl}, \mathrm{KOH}, \mathrm{HF}, \mathrm{HCl}$, Acetolysis, $\mathrm{KOH})$ and were eventually embedded in glycerine. Identification and counting of pollen grains (at least 400 pollen grains of terrestrial plants) was conducted under a light microscope at $400 \times$ magnification with the aid of identification keys (e.g. Moore and Webb 1991) and atlases (Reille 1992). Percentages were calculated upon the terrestrial pollen sum including tree, shrub, herb pollen, and fern spores. Loss on ignition (LOI) was measured at 550 and $950^{\circ} \mathrm{C}$ (following Heiri et al. 2001) to estimate the amount of organic matter, carbonate content, and minerogenic content (expressed in \% of total dry weight) of the sediment. Samples for ostracod analysis were prepared as described in Belis et al. (in press).

\section{Chronology}

The depth-age relationship is based on $13{ }^{14} \mathrm{C}$ AMS dates on terrestrial plant macrofossils (Finsinger 2004; Finsinger et al. 2006), and one additional ${ }^{14} \mathrm{C}$ date on wood (909 cm depth; $14,930 \pm 80{ }^{14} \mathrm{C}$ BP; Poz-6497), and by a distal micro-tephra layer, stratigraphically and chemically identified as the Laacher See Tephra (LST). The tephra was found with a discrete shard-peak concentration between 768 and $769 \mathrm{~cm}$, using a modified heavy liquid-separation technique (Blockley et al. 2005). It was chemically correlated (Table 1) to the LST by WDS electron microprobe, using a Cameca SX100 microprobe (for operating conditions see Table 1). The LST has been previously reported from this region (van den Bogaard and Schmincke 1985; Schmincke et al. 1999) and is a chemically distinct phonolitic eruption that is relatively easy to distinguish from Italian eruptions of the same period (Fig. 2a). For the LST, the weighted mean age of the middle cluster (i.e. $11,066 \pm 12{ }^{14} \mathrm{C}$ BP, Baales et al. 2002; 13,070-12,910 cal BP) was used. All radiocarbon dates were calibrated using the IntCal04 data set (Reimer et al. 2004) with the OxCal 3.1 program (Bronk Ramsey 1995, 2001). The depthage relationship (Fig. 2b) was established by means of a generalized mixed-effect regression (Heegaard et al. 2005). The LST was given a weight equal to one in order to guarantee a correct model-estimated age. Estimated $95 \%$ confidence intervals are $<200$ years 
Table 1 Chemical analyses of the Laacher See Tephra found at 768-769 $\mathrm{cm}$ depth at LPA

\begin{tabular}{|c|c|c|c|c|c|c|c|c|c|c|}
\hline $\mathrm{SiO}_{2}$ & $\mathrm{TiO}_{2}$ & $\mathrm{Al}_{2} \mathrm{O}_{3}$ & $\mathrm{FeO}$ & $\mathrm{MnO}$ & $\mathrm{MgO}$ & $\mathrm{CaO}$ & $\mathrm{Na}_{2} \mathrm{O}$ & $\mathrm{K}_{2} \mathrm{O}$ & $\mathrm{Cl}$ & Total \\
\hline 57.2 & 0.2 & 22.0 & 1.7 & 0.4 & 0.1 & 0.8 & 6.6 & 5.4 & 0.4 & 94.8 \\
\hline 58.3 & 0.5 & 19.3 & 2.2 & 0.2 & 0.3 & 1.8 & 5.5 & 7.1 & 0.2 & 95.4 \\
\hline 58.3 & 0.7 & 19.3 & 2.5 & 0.2 & 0.3 & 1.8 & 5.4 & 7.3 & 0.2 & 96.1 \\
\hline 59.7 & 0.6 & 20.1 & 2.0 & 0.1 & 0.3 & 1.8 & 4.7 & 7.2 & 0.2 & 96.8 \\
\hline 59.2 & 0.5 & 20.0 & 2.2 & 0.1 & 0.3 & 1.5 & 5.2 & 6.8 & 0.3 & 96.1 \\
\hline 59.6 & 0.3 & 20.1 & 1.9 & 0.1 & 0.2 & 1.6 & 6.2 & 7.3 & 0.3 & 97.6 \\
\hline 58.2 & 0.5 & 19.5 & 2.3 & 0.2 & 0.3 & 1.5 & 6.5 & 7.7 & 0.3 & 96.9 \\
\hline 58.9 & 0.5 & 19.2 & 2.4 & 0.2 & 0.3 & 1.5 & 5.5 & 7.1 & 0.3 & 95.8 \\
\hline 57.9 & 0.6 & 19.7 & 2.3 & 0.2 & 0.3 & 1.5 & 5.9 & 7.5 & 0.3 & 96.2 \\
\hline 59.1 & 0.5 & 19.2 & 2.4 & 0.1 & 0.3 & 1.5 & 5.4 & 7.0 & 0.3 & 95.8 \\
\hline 58.9 & 0.5 & 19.5 & 2.3 & 0.2 & 0.3 & 1.8 & 5.4 & 7.5 & 0.3 & 96.6 \\
\hline 55.8 & 0.1 & 22.8 & 1.5 & 0.3 & 0.1 & 0.5 & 9.8 & 4.4 & 0.4 & 95.7 \\
\hline 58.7 & 0.6 & 19.4 & 2.3 & 0.1 & 0.3 & 1.7 & 5.1 & 7.6 & 0.3 & 96.1 \\
\hline 58.4 & 0.2 & 20.0 & 2.1 & 0.2 & 0.2 & 1.6 & 7.0 & 7.2 & 0.3 & 97.2 \\
\hline 58.7 & 0.6 & 19.5 & 2.3 & 0.2 & 0.3 & 1.5 & 5.3 & 7.4 & 0.3 & 96.0 \\
\hline 59.3 & 0.6 & 19.8 & 2.3 & 0.2 & 0.3 & 1.6 & 4.9 & 7.4 & 0.3 & 96.7 \\
\hline
\end{tabular}

Samples were mounted in resin block and polished to a flat surface, microprobe operating conditions were 20 kev accelerating voltage, 10 na current and a $1 \mu \mathrm{m}$ beam rastering a $10 \mu \mathrm{m}$ spot size; Lipari Obsidian standards were used for secondary calibration and beam drift was monitored with reference to an Andradite standard. Samples with evidence of phenocryst inclusions and those with analytical totals below $95 \%$ were excluded from the results

for ages $<14,000 \mathrm{cal} \mathrm{BP}$ and increase to 300 years for ages $>15,700$ cal BP (Fig. 2b).

\section{Results}

Changes in sediment composition

The sediment has low organic and carbonate content until 14,400 cal BP (Fig. 3h). Thereafter, carbonate and organic content increase rapidly, while the ignition residue (Fig. 3i) decreases from ca. $\sim 90$ to $\sim 70 \%$ dry weight $(\% \mathrm{dw})$. Changes of smaller amplitude occur at $12,900 \mathrm{cal}$ BP when organic content slightly decreased, and at 11,400 cal BP when carbonate content increased to values $>20 \% \mathrm{dw}$.

\section{Stable isotopes}

Stable oxygen and carbon isotope ratios of bulk sediments $\left(\delta^{18} \mathrm{O}_{\mathrm{B}}\right.$ and $\delta^{13} \mathrm{C}_{\mathrm{B}}$, respectively) in sediments older than $\sim 15,500$ cal BP were high ( -6 and $>0 \%$, respectively, Fig. $3 \mathrm{c}$ ). Oxygen isotope ratios decreased to ca. $-8.0 \%$ between $\sim 15,200$ and $\sim 14,500$ cal BP, then rapidly increased to $-6.5 \%$ o between $\sim 14,500$ and $\sim 14,200$ cal BP, and later gradually decreased to $-9 \%$ at 9,500 cal BP. Highest $\delta^{13} \mathrm{C}_{\mathrm{B}}$ values occurred between $\sim 14,800$ and $\sim 14,200$ cal $\mathrm{BP}(\sim 0.5 \%)$. Between 14,600 and 14,200 cal BP $\delta^{13} C_{B}$ values decreased, then levelledoff at ca. $-3 \%$ until $\sim 11,500 \mathrm{cal} \mathrm{BP}$, and later decreased gradually to reach $-4.0 \%$ at 9,500 cal BP.

Pollen-inferred vegetation dynamics

With the climatic warming at the onset of the Bølling, the mixed and open woodland dominated by birch (Betula) and pine (Pinus) with large amounts of herbs (e.g. sagebrush (Artemisia)) and shrubs (e.g. juniper (Juniperus), not shown) was replaced by denser stands of Pinus and Betula (Fig. 3f-g). Summergreen oak (Quercus) populations expanded during the Allerød as inferred from higher pollen amounts. These oak populations partially collapsed during the YD period. Changing pollen abundances of Artemisia, Quercus, and Betula indicate that vegetation during the YD returned to an open woodland dominated by Betula, Pinus, and Artemisia and that at the onset of the Holocene oak populations recovered rapidly. 
Fig. 2 (a) $\mathrm{Al}_{2} \mathrm{O}_{3}$ vs $\mathrm{CaO}$ plot for the Avigliana data compared to summary proximal data for the middle and upper phases of the Laacher See Tephra (Schmincke et al. 1999) and major Italian eruptions from the late glacial (Wulf et al. 2004), (b) depth-age relationship of the sediment core AVP1. The two dashed lines indicate the upper and lower $95 \%$ confidence limits of the mean expected age throughout the sequence (central line); dots and error bars: mean calibrated ages and associated $2 \sigma$ errors; LST: Laacher See Tephra
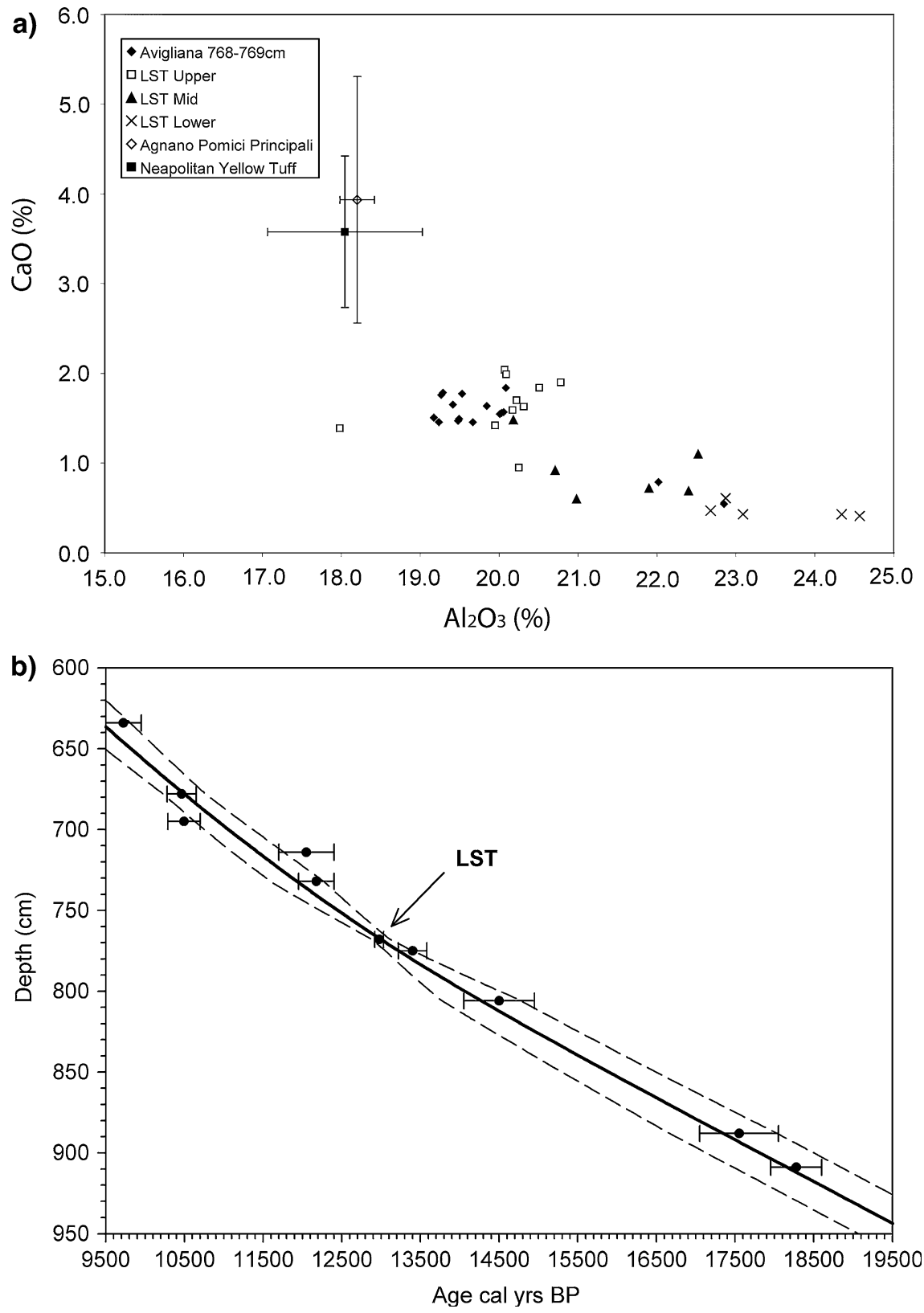

\section{Discussion}

Given the high ignition residue values (Fig. 3i), it is conceivable that bulk sediment $\delta^{18} \mathrm{O}_{\mathrm{B}}$ and $\delta^{13} \mathrm{C}_{\mathrm{B}}$ may be reflecting isotopic composition of detrital carbonates. This is especially the case for samples older than $14,450 \mathrm{cal} \mathrm{BP}$, when the sediment consisted of $>80 \%$ detrital material. For this period, the $\delta^{13} \mathrm{C}_{\mathrm{B}}$ values are in the range of -2 to $+1 \%$. Instead, for periods after
14,200 cal BP $\delta^{13} \mathrm{C}_{\mathrm{B}}$ values are around $-3 \%$. This suggests that equilibration with atmospheric $\mathrm{CO}_{2}$ and biological activity of plants enriched the dissolved bicarbonate with respect to groundwater (that has typically $\delta^{13} \mathrm{C}_{\mathrm{B}}$ values between -10 and $-15 \%$, Siegenthaler and Eicher 1986; Leng and Marshall 2004) throughout the record but to varying degrees. Neglecting evaporative enrichment and $\delta^{18} \mathrm{O}$ changes in sea water, the $\delta^{18} \mathrm{O}_{\mathrm{B}}$ composition will mainly covary 
Fig. 3 Comparison between the (a) NGRIP2$\delta^{18} \mathrm{O}$ record (after NGRIP Members 2004; Rasmussen et al. 2006), (b) Ammersee $\delta^{18} \mathrm{O}$ measured on benthic ostracods (von Grafenstein et al. 1999a), (c) stable isotopes measured on bulk carbonates (continuous line: $\delta^{18} \mathrm{O}_{\mathrm{B}}$; dotted line: $\delta^{13} \mathrm{C}_{\mathrm{B}}$ ), (d) $\delta^{18} \mathrm{O}$ of $C$. candida shells (open circles: juveniles; closed circles: adults), (e) $\delta^{13} \mathrm{C}$ of $C$. candida shells (open circles: juveniles; closed circles: adults), (f, g) selected pollen types, (h) organic and carbonate content $(\% \mathrm{dw})$, (i) ignition residue $(\% \mathrm{dw})$.

LST $=$ Laacher See Tephra. Thin grey area: onset of Bølling; large grey area Younger Dryas

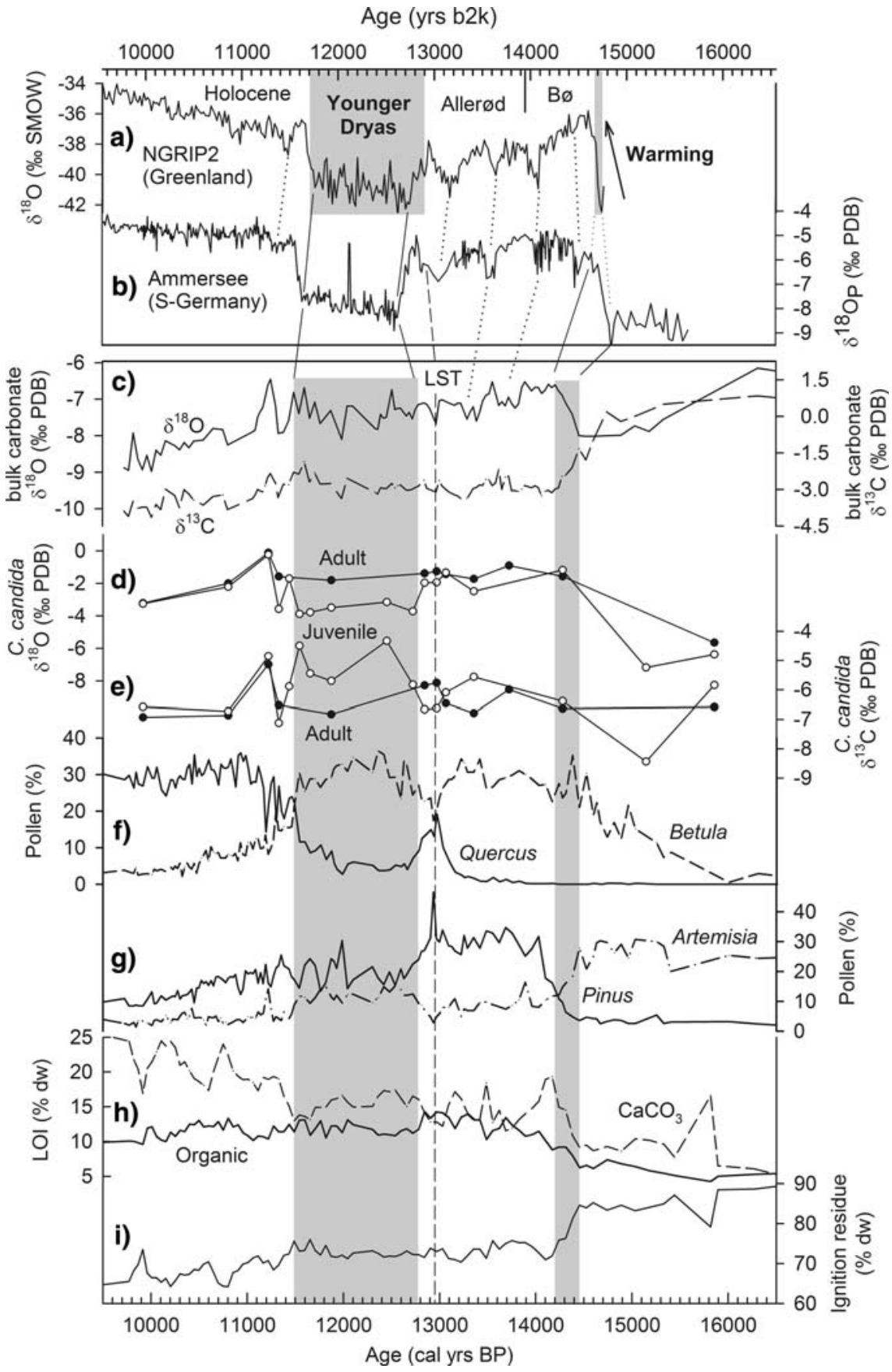

with temperature-with an increase of $\sim 0.36 \% /{ }^{\circ} \mathrm{C}$ (Siegenthaler and Eicher 1986). In contrast, $\delta^{13} \mathrm{C}_{\mathrm{B}}$ is indirectly related to climate due to the influence of inflowing waters (different isotopic composition), of $\mathrm{CO}_{2}$ exchange between atmosphere and lake water, of photosynthesis/respiration of aquatic plants within the lake (Leng and Marshall 2004), and of dissolved bicarbonate from the watershed, which can be affected by changes in the relative abundance of $\mathrm{C} 3(-25 \%)$ and $\mathrm{C} 4(-12 \%)$ plants in the catchment (e.g. Huang et al. 2001). Variations in $\delta^{13} \mathrm{C}_{\mathrm{B}}$ ratios may parallel those of $\delta^{18} \mathrm{O}_{\mathrm{B}}$ if productivity of aquatic vegetation responded to climate change, with relatively strong (weak) biological activity in warm (cold) phases 
Fig. 4 Scatter plot of $\delta^{18} \mathrm{O}_{\mathrm{B}}$ vs $\delta^{13} \mathrm{C}_{\mathrm{B}}$ for Lago Piccolo di Avigliana. Samples were classified following a 10-point running correlation

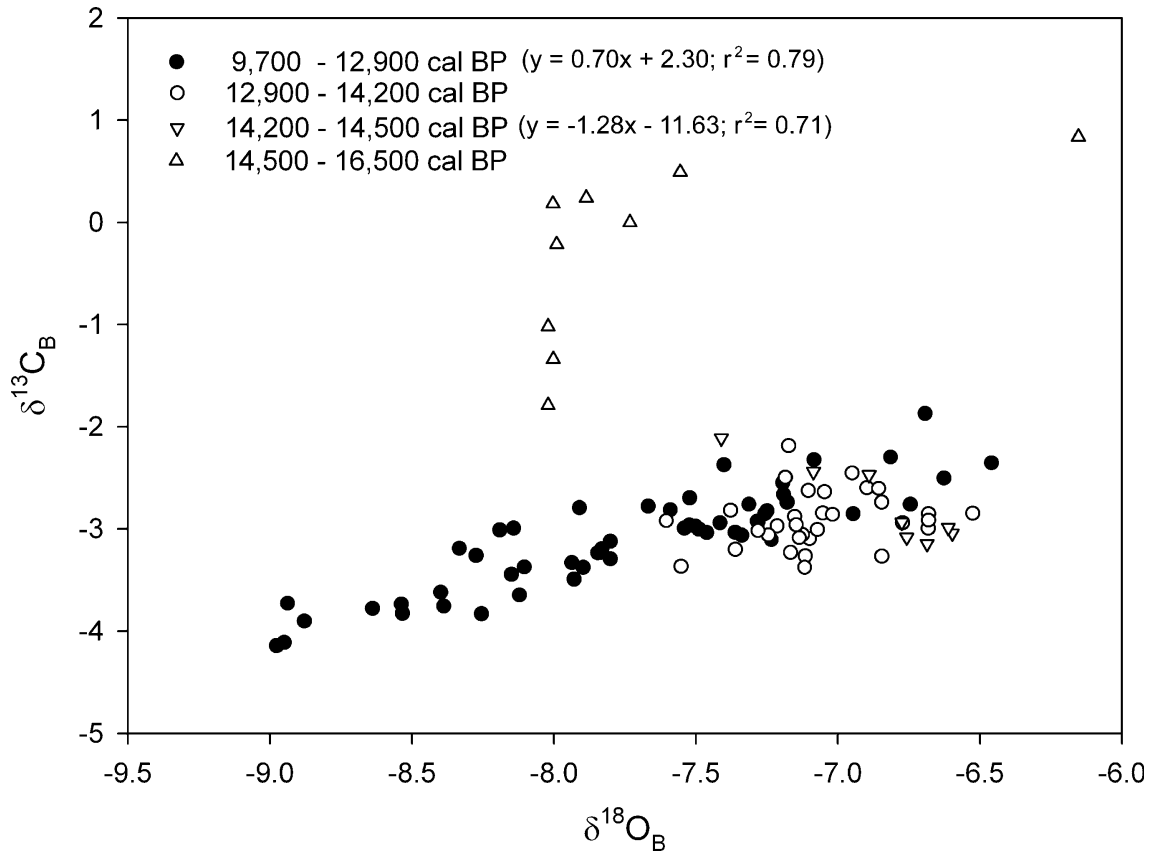

leading to enhanced (reduced) ${ }^{13} \mathrm{C}$ and ${ }^{18} \mathrm{O}$ enrichment in the water (Siegenthaler and Eicher 1986). When all samples are considered the linear correlation between $\delta^{18} \mathrm{O}_{\mathrm{B}}$ and $\delta^{13} \mathrm{C}_{\mathrm{B}}$ is low (Fig. 4). However, n-point running correlations $(\mathrm{n}=3,5$, and 10$)$ of $\delta^{18} \mathrm{O}_{\mathrm{B}}$ and $\delta^{13} \mathrm{C}_{\mathrm{B}}$ indicate that these isotopes are negatively correlated $(\mathrm{r} \leq-0.7)$ between $\sim 14,500$ and $\sim 14,200$ cal BP. The linear correlation coefficient between $\sim 14,200$ and $\sim 12,900$ cal $\mathrm{BP}$ is higher $(0.02 \leq \mathrm{r} \leq 0.6)$, while $\delta^{18} \mathrm{O}_{\mathrm{B}}$ and $\delta^{13} \mathrm{C}_{\mathrm{B}}$ covary ( $\mathrm{r} \geq 0.7$ ) starting from $\sim 12,900 \mathrm{cal} \mathrm{BP}$. The decrease in $\delta^{13} \mathrm{C}_{\mathrm{B}}$ (from $\sim+1 \%$ o to $\sim-3 \%$ ) between $\sim 14,800$ and $\sim 14,200$ cal $B P$ may reflect the successive establishment of terrestrial vegetation (expansion of Betula and Pinus, Fig. 3f-g) and related soil development in the lake's catchment as well as the smaller influence of detrital carbonate. As discussed by Hammarlund et al. (1999) on the basis of similar carbon-isotope records from Sweden, this development can lead to increased release of ${ }^{13} \mathrm{C}$-depleted $\mathrm{CO}_{2}$ from soil respiration and successive depletion with time in ${ }^{13} \mathrm{C}$ of dissolved inorganic carbon (DIC) in groundwater and lakes.

Rising $\delta^{18} \mathrm{O}_{\mathrm{B}}$ values at $\sim 14,500$ cal BP may only indirectly indicate a warming climate. First, $\delta^{13} \mathrm{C}_{\mathrm{B}}$ values decreased $\sim 200$ years before the $\delta^{18} \mathrm{O}_{\mathrm{B}}$ change occurred, suggesting that the establishment of terrestrial vegetation and related soil development preceded the $\delta^{18} \mathrm{O}_{\mathrm{B}}$ change. Second, $\delta^{18} \mathrm{O}_{\mathrm{B}}$ values increase synchronously with the ignition-residue change and with the rapid closing of Pinus-Betula stands, suggesting that vegetation played an important role in soil stabilization thereby reducing sediment runoff. Slightly lower $\delta^{18} \mathrm{O}_{\mathrm{B}}$ values during the YD may point to a climate cooling, but the change is very subdued in this record as in other $\delta^{18} \mathrm{O}_{\mathrm{B}}$ records from the region (Eicher 1987). Decreasing $\delta^{13} \mathrm{C}_{\mathrm{B}}$ and $\delta^{18} \mathrm{O}_{\mathrm{B}}$ values starting from $\sim 11,500$ cal BP might be caused by increased input of groundwater or river water, which generally has low oxygen and carbon isotopic values. The decreasing trend was distinctly interrupted at $\sim 11,200 \mathrm{cal}$ BP by a short-term positive excursion of both isotope ratios. Since oxygen and carbon isotopes still covary during this positive excursion, the less depleted isotopic values might indicate decreased input of groundwater or river water.

In addition to bulk sediments, stable-isotope ratios of the freshwater ostracod Candona candida were analyzed because ostracod-isotope records are not affected by detrital carbonates. Oxygen isotope ratios of $C$. candida $\left(\delta^{18} \mathrm{O}_{\mathrm{C}}\right)$ are generally less depleted (by $\sim 4 \%$ ) than $\delta^{18} \mathrm{O}_{\mathrm{B}}$. One reason for this difference is certainly the large vital offset (ca. $+2.2 \%$ ), which 
seems to be constant for all instars as observed by von Grafenstein et al. (1999b).

C. candida is a benthic organism (Meisch 2000), whose juveniles form their shells during the warm season while adults grow from late fall to spring. $\delta^{18} \mathrm{O}$ values of modern juvenile Candoninae (incl. $C$. candida) shells in Ammersee (southern Germany) are depleted by up to $2 \%$ compared to adult shells (von Grafenstein et al. 1999b). Since the difference decreases with water depth and vanishes at about $20 \mathrm{~m}$, where seasonal water-temperature differences are subdued, the difference is likely related to the temperature-dependent fractionation between calcite and water $(\sim-0.25 \% / \mathrm{K}$, von Grafenstein et al. 1999b). Hence, if water-depth was $\sim 20 \mathrm{~m}$ at LPA, then the difference between juvenile and adult $\delta^{18} \mathrm{O}_{\mathrm{C}}$ would not be water-level dependent but would reflect seasonal changes in $\delta^{18} \mathrm{O}$ of lake water. The sediments of the studied section lie at $>6.5 \mathrm{~m}$ below the present-day sediment-water interface $(12.5 \mathrm{~m}$ water depth). Since it is unlikely that the outflow was lower than at present, we infer a maximum water depth of at least $\sim 19 \mathrm{~m}$. Under this scenario, the temperature-dependent fractionation between calcite and water could be considered more or less as constant, and $\delta^{18} \mathrm{O}_{\mathrm{C}}$ would parallel the $\delta^{18} \mathrm{O}$ of lake water, which, if the lake was an open system with a short water-residence time as it is at present, would be mainly influenced by $\delta^{18} \mathrm{O}$ of precipitation $\left(\delta^{18} \mathrm{O}_{\mathrm{P}}\right)$ (von Grafenstein et al. 1999a; Schwalb 2003). Based on these assumptions, we may infer that during most of the analyzed period the winter to summer difference remained constant since juvenile and adult $\delta^{18} \mathrm{O}_{\mathrm{C}}$ values are similar. A summer- $\delta^{18} \mathrm{O}_{\mathrm{P}}$ decrease during YD (12,850-11,650 cal BP) can be inferred from lower $\delta^{18} \mathrm{O}_{\mathrm{CJ}}$, while little can be said for winter (only one sample). Increasing $\delta^{13} \mathrm{C}_{\mathrm{CJ}}$ during this 1200-year-long cold phase might have been caused by a reduction of the summer inflow (hence drier climate), which would lead to an increase of $\delta^{13} \mathrm{C}_{\text {DIC }}$ in the lake. This is because DIC of inflowing water, with relatively negative $\delta^{13} \mathrm{C}$, compensates both lakeinternal processes of enrichment (net-sedimentary flux of organic matter and equilibration with atmospheric $\mathrm{CO}_{2}$, von Grafenstein et al. 2000). A decreased summer-water input might also be inferred from the abundance decrease of $C$. candida and the occurrence of Darwinula stevensoni (Belis et al. in press), which at present is an indicator of shallow water (0-12 $\mathrm{m}$ water depth) in modern lakes (Meisch 2000). After $\sim 11,500$ cal $\mathrm{BP}, \quad \delta^{18} \mathrm{O}_{\mathrm{C}}$ gradually decrease, only being interrupted by a positive shift at $\sim 11,200 \mathrm{cal}$ BP. During the latter event, higher $\delta^{18} \mathrm{O}_{\mathrm{C}}$ and $\delta^{13} \mathrm{C}_{\mathrm{C}}$ might indicate a return to pre-YD $\delta^{18} \mathrm{O}_{\mathrm{P}}$ conditions. However, since similar changes are depicted in $\delta_{\mathrm{B}}$ ratios, decreasing $\delta_{\mathrm{C}}$ values during the early Holocene may as well have been caused by increasing input of groundwater or river water, or by a concomitant onset of eutrophication in the lake.

Major changes in vegetation composition at LPA, as inferred from the pollen record, are contemporaneous with changes in $\delta^{18} \mathrm{O}_{\mathrm{C}}$ and $\delta^{13} \mathrm{C}_{\mathrm{C}}$ ratios (within the resolution limits of the $\delta^{18} \mathrm{O}_{\mathrm{C}}$ record; Fig. 3). At the onset of the $\mathrm{B} \emptyset$ lling, $\delta^{18} \mathrm{O}_{\mathrm{C}}$ increased when mixed-woodland dominated by Betula, Pinus, Larix, and Juniperus were replaced by denser stands of Pinus and Betula. During the $\mathrm{YD} \delta^{18} \mathrm{O}_{\mathrm{C}}$ decreased along with a partial collapse of mixed forests (e.g. Quercus) and the expansion of Betula and Artemisiadominated shrubland.

An increase at the onset of the Bølling, followed by a decrease during the YD and a subsequent increase at the $\mathrm{YD} /$ Holocene transition (YD/PB) has been observed in several $\delta^{18} \mathrm{O}$ records of lacustrine carbonates in Central and northern Europe (e.g. Eicher and Siegenthaler 1976; Lotter et al. 1992; von Grafenstein et al. 1999a) and of ice-cores in Greenland (e.g. NGRIP, Rasmussen et al. 2006). The change in $\delta^{18} \mathrm{O}$ values is interpreted as reflecting changes in air temperatures. For the lacustrine records the main assumption states that variations of the drainage-basin water balance (precipitationevaporation) and of the long-term humidity have only negligible effect (Eicher and Siegenthaler 1976; von Grafenstein et al. 1999a). A similar sequence of Julyair temperature changes is confirmed for the Southern European Alps by chironomid-inferred temperature records at LPA and Lago di Lavarone (Heiri et al. 2007; Larocque and Finsinger 2008).

In contrast to Central European $\delta^{18} \mathrm{O}$ records, an increase in the $\delta^{18} \mathrm{O}$ values during the $\mathrm{YD}$ and a strong decrease in the $\delta^{18} \mathrm{O}$ values at the $\mathrm{YD} / \mathrm{PB}$ transition has been observed in several records from the Mediterranean region (Fig. 1), like in the speleothem record of the Soreq Cave and in lacustrine carbonates in Lake Lisan, Israel (Bar-Matthews et al. 2003; Kolodny et al. 2005), in Lake Van and in Eski 
Acıgöl, Turkey (Roberts et al. 2001; Wick et al. 2003), in Lake Zeribar and Lake Mirabad, Iran (Stevens et al. 2001, 2006), in Lake Pergusa, southern Italy (Zanchetta et al. 2007), and in the speleothem record from Grotta Savi, northeastern Italy (Fisia et al. 2005). A decrease in $\delta^{18} \mathrm{O}$ ratios during the early Holocene has also been observed in two records from the southeastern Alps: at Lake Terlago (Baroni et al. 2001) and at Lake Frassino (Baroni et al. 2006). These records have been interpreted as reflecting changes in the seasonality of precipitation (Lake Zeribar and Lake Mirabad), changes in the isotopic composition of source moisture and rainfall amount (Soreq Cave, Lake Lisan, and Lake Pergusa), or changes in the water balance of the lake (Eski Acıgöl), the amount of rainfall (Lake Frassino and Lake Terlago), and the combined effect of temperature and rainfall (Grotta Savi).

During the YD, as during other North Atlantic cold spells (e.g. Heinrich events), climatic conditions were generally drier in the southern Mediterranean region (e.g. Lamb et al. 1995; Combourieu Nebout et al. 2002) leading to higher $\delta^{18} \mathrm{O}$ ratios in lacustrine and speleothem carbonates. Wright et al. (2003) suggested that somewhere between the southern Mediterranean and Central Europe isotopic depletion due to temperature decrease and isotopic enrichment due to evaporation could have balanced each other if cool and dry YD climatic conditions occurred. As suggested by our $\delta^{18} \mathrm{O}_{\mathrm{C}}$ record, which shows more negative values during the $\mathrm{YD}$, this is clearly not the case for the Southern European Alps although chironomid-inferred temperatures indicate a temperature decrease (Heiri et al. 2007; Larocque and Finsinger 2008) and higher $\delta^{13} \mathrm{C}_{\mathrm{C}}$ values suggest a decreased inflow.

It is noteworthy that, within the limits of the stratigraphic resolution, the LPA $\delta^{18} \mathrm{O}_{\mathrm{C}}$-inferred climate changes during the late glacial show similar changes as those reconstructed for the same time-slice in Central Europe (e.g. Ammersee, von Grafenstein et al. 1999a, Fig. 4) and in the North Atlantic (Alley 2000). In contrast, soon after the onset of the Holocene, the patterns at LPA and Central Europe diverge with decreasing $\delta^{18} \mathrm{O}_{\mathrm{C}}$ at LPA and increasing $\delta^{18} \mathrm{O}$ ratios north of the Alps. Thus, $\delta^{18} \mathrm{O}_{\mathrm{C}}$ changes at LPA do not reflect a typical 'Central European' (e.g. Ammersee, Fig. 4) or 'Mediterranean' pattern (e.g. Soreq Cave). Instead, they seem to reflect a 'Central European' pattern for the late glacial (increasing values at the onset of the $\mathrm{B} \varnothing$ lling and decreasing $\delta^{18} \mathrm{O}_{\mathrm{C}}$ values during the YD) and a 'Mediterranean' pattern for the early Holocene (decreasing $\delta^{18} \mathrm{O}_{\mathrm{C}}$ values).

\section{Conclusions}

The Lago Piccolo di Avigliana sediments reflect the impact of major late glacial and early Holocene climate changes on sediment and vegetation composition, stable isotopes of bulk sediments, and more clearly, on stable isotopes of monospecific freshwater ostracod ( $C$. candida) shells. While oxygen and carbon isotope ratios of bulk sediments may be affected by detrital carbonates and, therefore, only indirectly record climate changes, stable isotopes measured on ostracods provide evidence for the onset of the Bølling warming and the YD cooling. During the late glacial the climate changes were, therefore, similar to those documented in Central Europe, as also inferred using chironomid-based temperature reconstructions in the Southern European Alps. In contrast, during the early Holocene the record does not show a climate warming as other records do in Central Europe, but rather suggests that the lake received gradually increasing input of groundwater or river water. This is also reflected in other stable isotope records from the Southern European Alps and from the Mediterranean region. However, many questions remain concerning climate changes and their impact on terrestrial and aquatic environments of the region. Further efforts are required to develop higher-resolution climate reconstructions in order to highlight late glacial and Holocene centennial-scale climate changes and changes in climate gradients across Southern and Central Europe.

Acknowledgements We are thankful to two anonymous reviewers for perceptive comments on this manuscript. This study was financially supported by the University of Bern, Research Group of Paleoecology and by the Swiss National Science Foundation with a Post-doc Fellowship to WF (Grant no. PBBE2-108573) and is Netherlands Research School of Sedimentary Geology publication no. 2007.10.17.

Open Access This article is distributed under the terms of the Creative Commons Attribution Noncommercial License which permits any noncommercial use, distribution, and reproduction in any medium, provided the original author(s) and source are credited. 


\section{References}

Alley RB (2000) The Younger Dryas cold interval as viewed from central Greenland. Quat Sci Rev 19:213-226

Alley RB (2007) Wally was right: predictive ability of the North Atlantic "conveyor belt" hypothesis for abrupt climate change. Annu Rev Earth Planet Sci 35:241-272

Baales M, Jöris O, Street M, Bittmann F, Wiethold J (2002) Impact of the Late Glacial Eruption of the Laacher See Volcano, Central Rhineland, Germany. Quat Res 58:273-288

Bar-Matthews M, Ayalon A, Kaufman A (1997) Late quaternary paleoclimate in the eastern Mediterranean region from stable isotope analysis of speleothems at Soreq Cave, Israel. Quat Res 47:155-168

Bar-Matthews M, Ayalon A, Kaufman A, Wasserburg GJ (1999) The Eastern Mediterranean paleoclimate as a reflection of regional events: Soreq cave, Israel. Earth Planet Sci Lett 166:85-95

Bar-Matthews M, Ayalon A, Gilmour M, Matthews A, Hawkesworth CJ (2003) Sea-land oxygen isotopic relationships from planktonic foraminifera and speleothems in the Eastern Mediterranean region and their implication for paleorainfall during interglacial intervals. Geochim Cosmochim Acta 67:3181-3199

Baroni C, Bruschi G, Veronese L, Zanchetta G (2001) Younger Dryas to early Holocene palaeoenvironmental evolution of the Lake Terlago (Southern Alps). Geogr Fis Dinam Quat 24:13-24

Baroni C, Zanchetta G, Fallick AE, Longinelli A (2006) Mollusca stable isotope record of a core from Lake Frassino, northern Italy: hydrological and climatic changes during the last $14 \mathrm{ka}$. Holocene 16:827-837

Belis CA, Finsinger W, Ammann B (in press) A Late-glacial ostracod and pollen record from Lago Piccolo di Avigliana (Northern Italy). Palaeogeogr Palaeoclimatol Palaeoecol

Biancotti A, Bellardone GSB, Cagnazzi B, Giacomelli L, Marchisio C (1998) Regional distribution of rainfalls and temperatures. Climatol Stud Piedmont 1:1-80

Blockley SPE, Pyne-O'Donnell SDF, Lowe JJ, Matthews IP, Pollard AM, Turney CSM, Molyneux EG (2005) A new and less destructive laboratory procedure for the physical separation of distal glass tephra shards from sediments. Quat Sci Rev 24:1952-1960

Bronk Ramsey C (1995) Radiocarbon calibration and analysis of stratigraphy: the OxCal program. Radiocarbon 37:425430

Bronk Ramsey C (2001) Development of the radiocarbon program OxCal. Radiocarbon 43:355-363

Carraro F, Cadoppi P, Castelletto M, Sacchi R, Baggio P, Giraud V, Bellardone G (2002) Note Illustrative della Carta Geologica d'Italia alla scala 1:50 000, Foglio 154Susa. Regione Piemonte, Torino

Combourieu Nebout N, Turon JL, Zahn R, Capotondi L, Londeix L, Pahnke K (2002) Enhanced aridity and atmospheric high-pressure stability over the western Mediterranean during the North Atlantic cold events of the past 50 k.y. Geology 30:863-866

Dray M, Jusserand C, Novel JP, Zuppi GM (1997) Air mass circulation and the isotopic 'shadow effect' in precipitation in the french and italian Alps, Isotope techniques in the study of environmental change. Proceedings Series, IAEA, Vienna, pp 107-117

Eicher U (1987) Die spätglazialen sowie die frühpostglazialen Klimaverhältnisse im Bereiche der Alpen: Sauerstoffisotopenkurven kalkhaltiger Sedimente. Geogr Helv 42:99-104

Eicher U, Siegenthaler U (1976) Palynological and oxygen isotope investigations on Late Glacial sediment cores from Swiss lakes. Boreas 5:109-117

Finsinger W (2004) Forest dynamics under changing climates: history of vegetation and climate in Northwestern Italy. $\mathrm{PhD}$ Thesis, University of Bern, Bern, $102 \mathrm{pp}$

Finsinger W, Tinner W, van der Knaap WO, Ammann B (2006) The expansion of hazel (Corylus avellana L.) in the southern Alps: a key for understanding its early Holocene history in Europe? Quat Sci Rev 25:612-631

Frisia S, Borsato A, Spötl C, Villa IM, Cucchi F (2005) Climate variability in the SE Alps of Italy over the past 17000 years reconstructed from a stalagmite record. Boreas 34:445-455

Gaggino GF, Cappelletti E (1984) Lago Piccolo di Avigliana, Catasto dei Laghi Italiani. Quaderni dell'Istituto di Ricerca sulle Acque 1:58-61

Hammarlund D, Edwards TWD, Björck S, Buchardt B, Wohlfahrt B (1999) Climate and environment during the Younger Dryas (GS-1) as reflected by composite stable isotope records of lacustrine carbonates at Torreberga, southern Sweden. J Quat Sci 14:17-28

Heegaard E, Birks HJB, Telford RJ (2005) Relationships between calibrated ages and depth in stratigraphical sequences: an estimation procedure by mixed-effect regression. Holocene 15:612-618

Heiri O, Lotter AF, Lemcke G (2001) Loss on ignition as a method for estimating organic and carbonate content in sediments: reproducibility and comparability of results. J Paleolimnol 25:101-110

Heiri O, Filippi ML, Lotter AF (2007) Lateglacial summer temperature in the Trentino area (Northern Italy) as reconstructed by fossil chironomid assemblages in Lago di Lavarone (1100 m a.s.l.). Stud Trent Sci Nat Acta Geol 82:299-308

Huang Y, Street-Perrott FA, Metcalfe SE, Brenner M, Moreland M, Freeman KH (2001) Climate change as the dominant control on glacial-interglacial variations in $\mathrm{C} 3$ and C4 plant abundance. Science 293:1647-1651

Kolodny Y, Stein M, Machlus M (2005) Sea-rain-lake relation in the Last Glacial East Mediterranean revealed by $\delta^{18} \mathrm{O}$ $\delta^{13} \mathrm{C}$ in Lake Lisan aragonites. Geochim Cosmochim Acta 69:4045-4060

Lamb H, Gasse F, Benkaddour A, El Hamouti N, van der Kaars S, Perkins WT, Pearce NJ, Roberts CN (1995) Relation between century-scale Holocene arid intervals in tropical and temperate zones. Nature 373:134-137

Larocque I, Finsinger W (2008) Late-glacial temperature reconstruction using chironomids preserved in Lago Piccolo di Avigliana in the southern Alps. Palaeogeogr Palaeoclimatol Palaeoecol 257:207-223. doi:10.1016/ j.palaeo.2007.10.021

Leng MJ, Marshall JD (2004) Palaeoclimate interpretation of stable isotope data from lake sediment archives. Quat Sci Rev 23:811-831 
Longinelli A, Selmo E (2003) Isotopic composition of precipitation in Italy: a first overall map. J Hydrol 270:75-88

Lotter AF, Eicher U, Siegenthaler U, Birks HJB (1992) Lateglacial climatic oscillations as recorded in Swiss lake sediments. J Quat Sci 7:187-204

Meisch C (2000) Freshwater ostracoda of Western and Central Europe. Spektrum Akademischer Verlag, Heidelberg/ Berlin

Merkt J, Streif H (1970) Stechrohr-Bohrgeräte für limnische und marine Lockersedimente. Geol Jahrb 88:137-148

Moore PD, Webb JA, Collinson ME (1991) Pollen analysis. Blackwell Science Ltd, Oxford

NGRIP Members (2004) High-resolution record of Northern Hemisphere climate extending into the last interglacial period. Nature 431:147-151. doi:10.1038/nature02805

Petrucci F, Bortolami GC, Dal Piaz GV (1970) Ricerche sull'Anfiteatro morenico di Rivoli-Avigliana (Provincia di Torino) e sul suo substrato cristallino. Mem Soc Ital Sci Nat Mus Civ Stor Nat Milano 18:95-168

Pinna M (1977) Climatologia. UTET, Torino

Rasmussen SO, Andersen KK, Svensson AM, Steffensen JP, Vinther BM, Clausen HB, Siggaard-Andersen M-L, Johnsen SJ, Larsen LB, Dahl-Jensen D, Bigler M, Röthlisberger R, Fischer H, Goto-Azuma K, Hansson ME, Ruth U (2006) A new Greenland ice core chronology for the last glacial termination. J Geophys Res 111:D06102. doi:10.1029/2005JD006079

Reille M (1992) Pollen et spores d'Europe et d'Afrique du nord. Laboratoire de Botanique Historique et Palynologie, Marseille

Reimer PJ, Baillie MGL, Bard E, Bayliss A, Beck J, Bertrand CJH, Blackwell PG, Buck CE, Burr GS, Cutler KB, Damon PE, Edwards RL, Fairbanks RG, Friedrich M, Guilderson TP, Hogg AG, Hughen KA, Kromer B, McCormac G, Manning S, Ramsey CB, Reimer RW, Remmele S, Southon JR, Stuiver M, Talamo S, Taylor FW, van der Plicht J, Weyhenmeyer CE (2004) IntCal04 terrestrial radiocarbon age calibration, 0-26 Cal Kyr BP. Radiocarbon 46:1029-1058

Roberts N, Reed JM, Leng MJ, Kuzucuoglu C, Fontugne M, Bertaux J, Woldring $\mathrm{H}$, Bottema S, Black S, Hunt E, Karabiyikoglu M (2001) The tempo of Holocene climatic change in the eastern Mediterranean region: new highresolution crater-lake sediment data from central Turkey. Holocene 11:721-736

Schmincke HU, Park C, Harms E (1999) Evolution and environmental impacts of the eruption of Laacher See Volcano (Germany) 12,900 a BP. Quat Int 61:61-72

Schwalb A (2003) Lacustrine ostracodes as stable isotope recorders of late-glacial and Holocene environmental dynamics and climate. J Paleolimnol 29:267-351

Siegenthaler U, Eicher U (1986) Stable oxygen and carbon isotope analyses. In: Berglund BE (ed) Handbook of holocene palaeoecology and palaeohydrology. Wiley, Chichester, pp 407-422

Stevens LR, Wright HEJ, Ito E (2001) Proposed changes in seasonality of climate during the Lateglacial and Holocene at Lake Zeribar, Iran. Holocene 11:747-755

Stevens LR, Ito E, Schwalb A, Wright HE Jr (2006) Timing of atmospheric precipitation in the Zagros Mountains inferred from a multi-proxy record from Lake Mirabad, Iran. Quat Res 66:494-500

van den Bogaard P, Schmincke HU (1985) Laacher See Tephra: a widespread isochronous late Quaternary tephra layer in central and northern Europe. Geol Soc Am Bull 96:1554-1571

Vescovi E, Ravazzi C, Tinner W, Arpenti E, Finsinger W, Pini R, Valsecchi V, Wick L, Ammann B (2007) Interactions between climate and vegetation during the Lateglacial period as recorded by lake and mire sediment archives in Northern Italy and Southern Switzerland. Quat Sci Rev 26:1650-1669

von Grafenstein U, Erlenkeuser H, Brauer A, Jouzel J, Johnsen SJ (1999a) A Mid-European decadal isotope-climate record from 15,500 to 5000 years B.P. Science 284:1654-1657

von Grafenstein U, Erlenkeuser H, Trimborn P (1999b) Oxygen and carbon isotopes in modern fresh-water ostracod valves: assessing vital offsets and autecological effects of interest for palaeoclimate studies. Palaeogeogr Palaeoclimatol Palaeoecol 148:133-152

von Grafenstein U, Eicher U, Erlenkeuser H, Ruch P, Schwander J, Ammann B (2000) Isotope signature of the Younger Dryas and two minor oscillations at Gerzensee (Switzerland): palaeoclimatic and palaeolimnologic interpretation based on bulk and biogenic carbonates. Palaeogeogr Palaeoclimatol Palaeoecol 159:215-229

Wick L, Lemcke G, Sturm M (2003) Evidence of Lateglacial and Holocene climatic change and human impact in eastern Anatolia: high-resolution pollen, charcoal, isotopic and geochemical records from the laminated sediments of Lake Van, Turkey. Holocene 13:665-675

Wright HE, Ammann B, Stefanova I, Atanassova J, Margalitadze N, Wick L, Blyakharchuk TA (2003) Late-glacial and Early-Holocene dry climates from the Balkan Peninsula to Southern Siberia. In: Tonkov S (ed) Aspects of palynology and palaeoecology. PENSOFT Publishers, Sofia-Moscow, pp 127-136

Wulf S, Kraml M, Brauer A, Keller J, Negendank JFW (2004) Tephrochronology of the $100 \mathrm{ka}$ lacustrine sediment record of Lago Grande di Monticchio (southern Italy). Quat Int 122:7-30. doi:10.1016/j.quaint.2004.01.028

Zanchetta G, Borghini A, Fallick AE, Bonadonna FP, Leone G (2007) Late Quaternary palaeohydrology of Lake Pergusa (Sicily, southern Italy) as inferred by stable isotopes of lacustrine carbonates. J Paleolimnol 38:227-239. doi: 10.1007/s10933-006-9070-1 